\title{
ЭТИЧЕСКАЯ СОСТАВЛЯЮЩАЯ СИСТЕМЫ ЭКОЛОГИЧЕСКОГО ОБРАЗОВАНИЯ В ЛЕТНЕМ ЭКОЛОГИЧЕСКОМ ЛАГЕРЕ
}

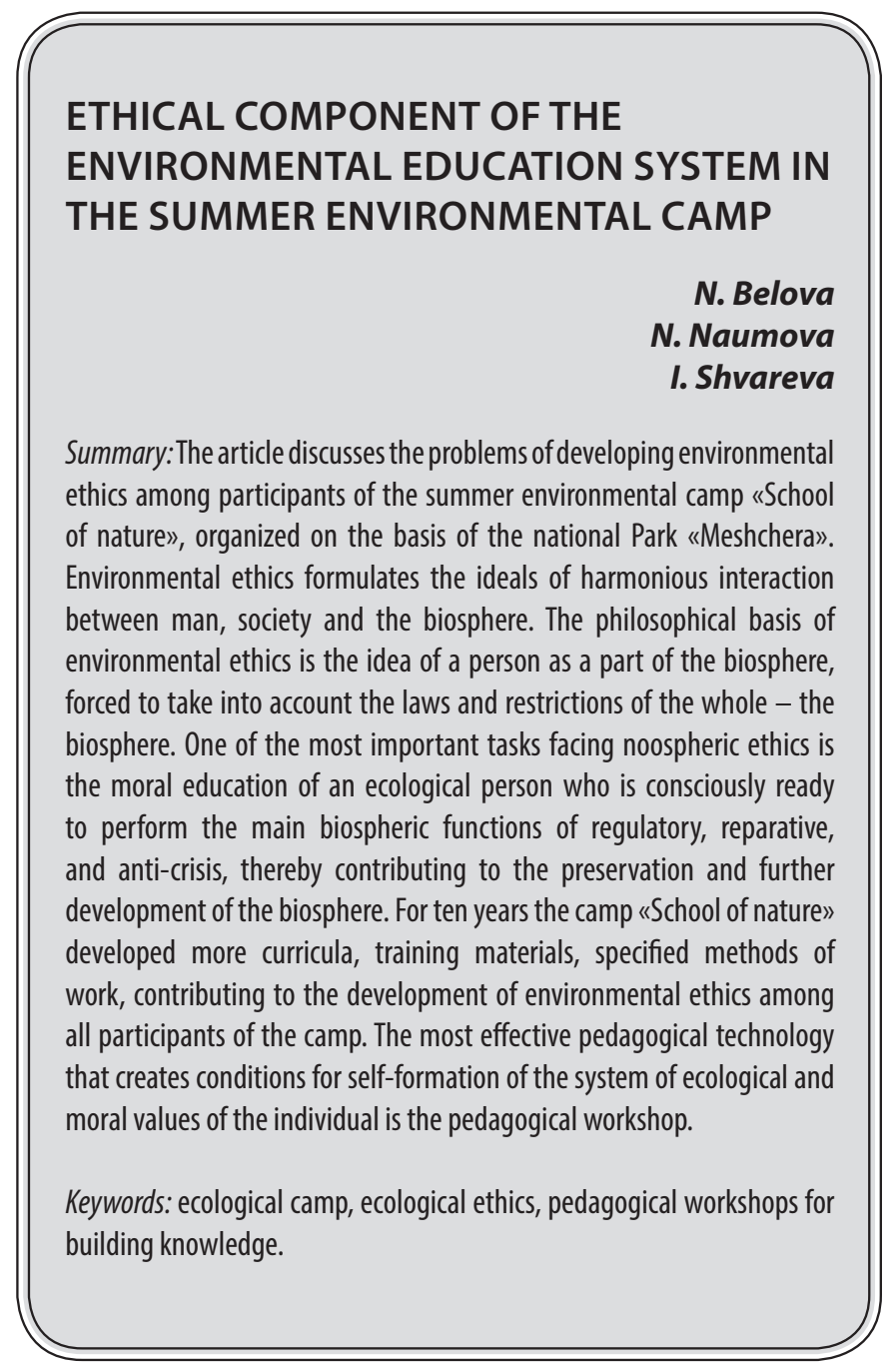

Белова Надежда Ивановна

K.n.н., доцент, Санкт-Петербургская Академия Постдипломного Педагогического Образования nadejda_belova@mail.ru

Наумова Наталья Николаевна

Д.п.н., профессор, Владимирский государственный университет им. А.Г. и Н.Г. Столетовых

nnnaumova@list.ru

Шварева Ирина Станиславовна

К.х.н., дочент, Ковровская государственная технологическая академия им. В.A. Дегтярева.

IShvar@yandex.ru

Аннотация: В статье обсуждаются проблемы развития экологической этики у участников летнего экологического лагеря «Школа природы», организованного на базе национального парка «Мещера». Экологическая этика формулирует идеалы гармоничного взаимодействия человека, общества и биосферы. Философскую основу экологической этики составляют представления о человеке как части биосферы, вынужденной в своей деятельности считаться с законами и ограничениями целого - биосферы. Одной из важнейших задач, стоящих перед ноосферной этикой, является нравственное воспитание экологической личности, осознанно готовой к выполнению основных биосферных функций регуляторной, репарационной, антикризисной, способствуя тем самым сохранению и дальнейшему развитию биосферы. За десять лет работы лагеря «Школа природы» разработаны авторские учебные программы, учебные пособия, определены методики работы, способствующие развитию экологической этики у всех участников лагеря. Наиболее воздейственной педагогической технологией, создающей условия для самоформирования системы эколого-нравственных ценностей личности, является педагогическая мастерская.

Ключевые слова: экологический лагерь, экологическая этика, педагогические мастерские построения знания.

в единое мировоззрение в рамках Мегаэкологии [10], и экологическая этика формирует идеалы гармонических взаимоотношений внутри системы Биосфера - Человек. [7] Под экологической этикой большинство современных экологов и педагогов понимает учение об этических отношениях человека с природой, основанных на восприятии природы как члена морального сообщества, морального партнера (субъекта), равноправии и равноценности всего живого, а также ограничении прав и потребностей человека [8]. В экологической этике закладываются основы новых моральных принципов, согласно которым человек выступает как часть природного целого и должен при любых обстоятельствах соизмерять свою деятельность с законами и ограничениями целого, и запрет «не убий» сегодня касается не только нашего ближнего, но и растений, животных, экосистем; расширяются представления о классических добродетелях 
[11], закладывается новая система ценностей. Как писал отец экологической этики О. Леопольд - экологическая этика - это ограничение свободы действий в борьбе за существование [6]. Примерно то же заявлял и другой основатель экологической этики А. Швейцер: «Самоотречение ради жизни из благоговения перед жизнью»[12]. Именно нравственные принципы экологической этики являются гарантом целостности экосистем и достойного качества жизни человека.

Между тем современное общество по-прежнему живет по заповедям антропоцентрической потребительской этики, которая высшим благом полагает достижение любой ценой наибольшего счастья для наибольшего числа людей, причем счастье чаще всего понимается в виде суммы конкретных материальных благ, а идеалом выступают популярные личности, проповедующие утилитаристские ценности. Эти этические образцы, вернее отсутствие их, - одна из причин экологического тупика нашего столетия.

Одной из важнейших задач, стоящих перед этикой XXI века современные философы считают осознание нравственных задач стоящих как перед отдельным человеком, так и перед человечеством в целом, задач, которые связаны, прежде всего, с сохранением биосферы, осуществлением в полной мере биосферных функций человечества: регуляторной, репарационной антикризисной. В. Хесле [11], размышляя о проблеме формирования человеческих качеств, необходимых для выживания биосферы, говорить о необходимости в рамках экологической этики формирования разумных аскетических идеалов, возвращения к Мере, причем не только в отношении демографической проблемы, но и в отношении структуры потребностей. Но главная этическая проблема большинству исследователей видится не в обосновании новых этических норм и принципов ради сохранения планеты, а в поиске стимулов и мотивов, способных побудить людей поступать соответствующим образом. В решении большинства поставленных проблем этика тесно взаимодействует с экологией, психологией и педагогикой, опираясь при этом на духовные поиски философов как предыдущих эпох, так и современных мыслителей.

Одной из самых сложных задач, которая стоит перед экологами и педагогами является создание условий, определенной педагогической фасилитативной среды, которые будут способствовать развитию экологической этики у современной молодежи. Необходим постоянный поиск педагогических методов и технологий, способствующих формированию экологической личности, обладающей научным мировоззрением и действующей в соответствии с требованиями экологического императива.[4]
Наши наблюдения показывают, что большим воздейственным потенциалом, способным изменить и систему нравственных ценностей подростка и его мотивации, обладает экологический лагерь. Этот же феномен быстрых позитивных изменений в структуре личности ребенка в условиях экологических экспедиций и полевых лагерей отмечен и другими исследователями. [13] В частности, исследования показывают, что длительное пребывание в гармоничных природных средах развивает способность школьников к субъектному восприятию элементов природы, активизирует их готовность к участию в различного рода природоохранных и природовосстанавливающих акциях.[5]

С 2011 года общественное движение «Школа природы» организует экологические лагеря на базе национального парка «Мещера». Одной из главных воспитательных задач, которую ставят перед собой руководители лагеря, является создание условий для развития экологической личности, обладающей научным мировоззрением и экологической ноосферной этикой. За десять лет работы лагеря сформировался большой творческий коллектив, объединяющий ученых-естественников из различных университетов Москвы, Санкт-Петербурга, Владимира, Коврова, психологов, школьных учителей, спортивных инструкторов. Разработаны оригинальные авторские образовательные программы, созданы учебные пособия, в основу которых положены принципы экологической этики.

Одним из главных видов деятельности детей в лагере является участие в мониторинговых исследования водно-болотных экосистем, осуществляемых в национальном паке «Мещера» и волонтерство. Эта реальная повседневная помощь конкретным природным объектам становится важной частью витагенного опыта каждого участника лагеря. Одним из условий этичного поведения в природных средах является знание о них, понимание законов экосистем и подчинение своей деятельности ограничениям и запретам, накладываемых этими законами, а это требует сформированного экологического мировоззрения. Знаниевая составляющая системы экологического образования в экологическом лагере «Школа природы» закладывается как в ходе работы школьников под руководством ученых над конкретными исследовательскими проектами, так и в результате освоения специально разработанного учебного курса «Экология для юных исследователей». Этические проблемы рассматриваются в каждом разделе курса, в рамках темы «Биосфера и ноосфера» приводится краткая история становления экологической этики как необходимого условия устойчивого развития, коэволюции природы и общества.

Необходимым условием для принятия личностью этической составляющей данного курса является вы- 
бор таких педагогических технологий, которые будут способствовать не только приобретению определенной системы знаний, но и мотивировать личность к совершению определенных природосообразных действий. Психологи отмечают, что можно выделить три уровня регуляции мотивации к совершению или не совершению поступков по отношению к природным объектам.[4] Первый уровень конформистский - регуляции извне: «я не могу причинить вред этому объекту природы, потому что общественное мнение будет не на моей стороне»; «так никто не делает»; «меня осудят соседи, родители, учителя» и т.п. Второй уровень - внутренние логические убеждения на уровне сформированного экологического знания: «так делать неправильно, поскольку подобное действие наносит ущерб природе, нарушает устойчивость природных экосистем» и т.п. И третий - глубинный уровень: «я так делать не могу, поскольку воспринимаю объект природы как живое существо (субъект); мне будет больно, если я причиню ему боль». Последнее свидетельствует о наличии экологического сознания «зеленого» типа, и подобные вопросы рассматривает глубинная экология.

Все три уровня мотивации хороши, если они сохранят жизнь реальному объекту природы, но в экологическом лагере «Школа природы» мы заняты созданием условий для освоения и присвоения нравственно-экологических ценностей второй и третьей систем регуляции. Такие условия создаются в современной (а для многих учителей - инновационной) образовательной технологии педагогической мастерской и проходят поверку практикой экологических походов и занятий по исследованию окружающей среды и изучению природных объектов и субъектов.

Условия для освоения нравственно-экологической ценности в педагогической мастерской обеспечиваются ее главным свойством - жизнесообразностью. Учебнопознавательный процесс в мастерской организован аналогично познавательному процессу в обыденной жизни человека. Технологическая конструкция педагогической мастерской естественным образом подходит для осуществления проживания образовательной линии каждого участника. Под проживанием понимается бытие - существование, "здесь и сейчас" в качестве субъекта, то есть носителя деятельности, предложенной в рамках данной образовательной технологии (шире - организации любого деятельностного процесса). Это “пребывание в", а не "присутствие на...". Неосознанное включение происходит на первом этапе - индукции. Последний этап - рефлексия, здесь происходит анализ, осознавание проживания, которое приводит к осознанию, что ответственность за получение результата деятельности лежит на самом субъекте деятельности.

Такие важные этапы мастерской, как само- (подумай и сделай сам) и социоконструкция (обсуди и сделай с другими), разные виды социализации (предъяви другим - людям или группам) также созданы для проживания, то есть участия в ней не в роли присутствующего, а в качестве действующего и взаимодействующего человека [1]. И, как правило, любое проживание - активное или пассивное - отражает настоящую жизненную позицию каждого участника. Особенно этому способствуют встроенные в мастерскую упражнения типа «активитес», которые позволяют событиям развиваться так, как аналогичную ситуацию прожили бы участники в реальной жизни, потому что мировоззрение всегда проявляется в поступке, а нравственно-ценностное ориентирование, как учит этика, возможно только в действии [2].

Обучение в мастерской происходит как в жизни: чтобы человек начал познавательный поиск, сначала у него должна появиться - актуализироваться - причина или потребность узнать; тогда он ищет информацию, нуждается в ней; если появляются трудности, человек идет к людям, общается, его общение при этом из простой коммуникации становится смысловым; сверяет полученное знание с «истиной» другой группы людей; делает выбор в пользу той или иной ценности, осмысляет ценность и значимость своего выбора; поверяет практикой, анализирует; присваивает осмысленное знание или ценность. Таков житейский, бытийный ход человеческого поиска знания, ценности, смысла и таково направление проживания в педагогической мастерской, таков четко заданный алгоритм мастерской.

Педагогическая мастерская, как наиболее подходящая для освоения этических правил, установок, ценностей технология, характеризуется нелинейностью ее логики; высокой степенью неопределенности в формулировании заданий; актуализацией личностных историй и опыта; появлением вопросительной позиции обучающихся [1].Эти характеристики можно отнести и к реальной жизни - алгоритм может планироваться для получения вероятностного результата. Мастерская, как и жизнь, создает условия для освоения, усвоения, «примерки» в проживаемых ситуациях и присвоения некоей ценности через личностное проживание; предоставляет выбор. Знание о ценности участник получит даже при пассивной позиции. Но гораздо важнее то, что за выбором ценности стоит ответственность. И каждая прожитая мастерская добавляет осознанности в деятельностный выбор.

Поэтому в условиях экологического лагеря мы даем детям возможность прожить целый ряд мастерских с экологическим и этическим содержанием [3]. В них этика благоговения перед жизнью Альберта Швейцера познается через упражнения активитесы, позволяющие практически сравнить разные этические позиции, обнаружить несовершенство своей собственной и осуще- 
ствить осознанный отказ от нее в пользу той, что явилась открытием. Четыре закона экологии Барри Коммонера тоже узнаются не через готовые тексты, а «открываются» с помощью театрализаций, в которых участник побывает и режиссером, и актером, и сочинителем афиш. Экологические правила жизни в самом лагере и правила счастливого сосуществования всех друг с другом (включая детей, взрослых, змей, ежей и редких и нередких растений) тоже никто не продиктует, их ежегодно «создают» и потому с легкостью исполняют «создатели», договорившиеся им следовать. И среди этих правил работает Правило доверия, без которого невозможна ни одна мастерская [2], потому что оно создает доверительное пространство. И это пространство хорошо организованной свободы для изменения целеполагания, для роста самоосознавания, для самоорганизации всем участникам мастерской, включая мастера, ее ведущего.

Таким образом, технология мастерской с ее педагогической философией, жизнесообразным алгоритмом проживания, многообразными способами действия и взаимодействия, индуктивной логикой и обязательной рефлексией создает все необходимые условия для выработки участниками целостного знания о нравственных высотах и пути к ним. В пространстве мастерской происходит освоение участниками этического закона через действие и осознавание. Такое вхождение в ценности делает их принятие в мировоззрение осознанным, превращает их в личностные морально-этические установки, определяющими экологически нравственное поведение человека.

Опыт экологического лагеря «Школы природы» свидетельствует, что развитие экологической этики, самоформирование системы эколого-нравственных ценностей, ноосферных идеалов, готовности к природосообразной деятельности обеспечивается системой тщательно продуманных педагогических действий, включающих использование метода исследований, волонтерства, личностно-ориентированных интерактивных педагогических технологий.

\section{ЛИТЕРАТУРА}

1. Белова Н.И. Педагогическая мастерская как средство развития личности участников образовательной деятельности: дис. на соис. учен.степени к-та пед. наук. СПб., СПГУПМ, 2000.

2. Белова Н.И., Орлова О.В. Технология педагогических мастерских: вхождение в ценности. Москва, 2019. -320с.

3. Белова Н.И., Наумова Н.Н. Экология в мастерских. - СПб.: Паритет, 2004. - 224 с.

4. Дерябо С.Д., Ясвин В.А. Экологическая педагогика и психология. - Ростов на/Д.: Изд-во Феникс, 1996. - 480 с.

5. Дорошко М.Н. Организация летних туристских лагерей как средство гармоничного развития личности// Современная высшая школа.2012. №1. С. 203206.

6. Леопольд 0. Календарь песчаного графства. М.: Мир,1983.

7. Моисеев Н.Н. Коэволюция природы и общества // Экология и жизнь. - 1997. - № 2-3. - С.12-16.

8. Сатиров В.А., Пустовойтов В.В. Социальная экология. - М.: Издательский центр «Академия», 2000. - 280 с.

9. Софронов Р.П., Товарищева Ф.Д. Воспитание экологической культуры у учащихся в условиях летнего экологического лагеря // Ученые записки. Электронный научный журнал Курского государственного университета. 2014. №4 (32). URL: https://cyberleninka.ru/article/n/vospitanie-ekologicheskoy-kultury-uuchaschihsya-v-usloviyah-letnego-ekologicheskogo-lagerya (дата обращения: 02.02.2020).

10. Реймерс Н.Ф. Экология (теории, законы, правила и гипотезы). - М.: Россия молодая, 1994. - 356 с.

11. Хесле В. Философия и экология. - М.: Издательская фирма АО Ками, 1994. - 192 с.

12. Швейцер А. Благоговение перед жизнью. - М.: Прогресс, 1992. - 573 с.

13. Школа Друзей природы. Из опыта организации и проведения экологических лагерей и экспедиций для школьников на 00ПТ/под ред. И.Ю. Головиной [и др.]. М.: ЭкоЦентр «Заповедники». 2012. 44 с.

14. Шрейдер Ю.А. Этика. Введение в предмет. - М.:Лань, 1998. 271 с.

(с Белова Надежда Ивановна (nadejda_belova@mail.ru), Наумова Наталья Николаевна (nnnaumova@list.ru), Шварева Ирина Станиславовна (IShvar@yandex.ru). 